Sains Malaysiana 50(5)(2021): 1425-1431

http://doi.org/10.17576/jsm-2021-5005-21

\title{
Ascites in a Patient with Hairy Cell Leukaemia and Carcinoma of Breast: A Diagnostic Challenge
}

(Asites pada Pesakit Leukaemia Sel Berbulu dan Karsinoma Payudara: Suatu Cabaran Diagnosis)

\author{
Wint Wint Thu Nyunt, Azian Naila binti Md Nor, Noralisa Abdul Karim, Tang Yee Loong, S Fadilah \\ S ABDUL WAHID* \& NOR RAFEAH TUMIAN
}

\begin{abstract}
Hairy cell leukaemia (HCL) is a rare indolent B-cell lymphoproliferative disorder. We report a diagnostic challenge in detecting the cause of ascites, which is a rare, unique manifestation of HCL. A 72-year-old lady presented with 1-monthhistory of pain in left upper abdomen and loss of weight. There was hepatomegaly, splenomegaly, bilateral inguinal lymphadenopathy, anaemia, and lymphocytosis. She was diagnosed as HCL, based on morphology, immunophenotyping of peripheral blood and bone marrow biopsy examination. In 2009, she was diagnosed as carcinoma of breast when she presented with a mass in left breast; and she received treatment. For HCL, she received intermittent chemotherapy (Chlorambucil+ Prednisolone). Her HCL was stable until 2018 when she presented with recurrent ascites which needed frequent, regular peritoneal paracentesis. Since she had HCL and carcinoma of breast, determining the aetiology of ascites was challenging. Possible causes of her ascites included metastatic carcinoma of breast, HCL, cirrhosis of liver with portal hypertension and peritoneal tuberculosis. Cytology of peritoneal fluid showed mature-looking lymphocytes but no malignant cells. Interestingly, flow cytometry analysis of peritoneal fluid showed the presence of clonal B cell population with lambda light chain restriction. Therefore, it was concluded that her ascites was a manifestation of HCL. A few months later, she succumbed to septicaemia. Impact of ascites on disease course of HCL included rapid disease progression, poor prognosis and shortened survival. We highlight the important role of immunophenotyping in addition to cytomorphology to guide us in confirming the aetiology of ascites in a patient with haematological and solid organ malignancies.
\end{abstract}

ABSTRACT

Keywords: Ascites; flow cytometry; hairy cell leukaemia; immunophenotyping

\section{ABSTRAK}

Leukaemia sel berbulu (HCL) merupakan penyakit limfoproliferatif sel-B indolen yang jarang berlaku. Kami melaporkan cabaran diagnosis dalam mengesan penyebab asites, iaitu manifestasi HCL yang luar biasa dan unik. Seorang wanita berumur 72 tahun menunjukkan sejarah kesakitan di bahagian kiri atas abdomen selama sebulan dan penurunan berat badan. Terdapat hepatomegali, splenomegali, limfadenopati inguinal bilateral, anaemia dan limfositosis. Beliau didiagnos sebagai HCL berdasarkan morfologi, imunofenotip darah periferi dan pemeriksaan biopsi sumsum tulang. Pada tahun 2009, beliau didiagnos pula dengan karsinoma payudara apabila terdapat gumpalan pada payudara kiri dan beliau telah menerima rawatan. Bagi HCL, beliau menerima kemoterapi bersela (Chlorambucil+Prednisolone). Penyakit HCL beliau stabil sehingga tahun 2018 apabila beliau mengalami asites berulang dan memerlukan parasentesis peritoneum yang kerap. Oleh kerana beliau menghidap HCL dan karsinoma payudara, penentuan etiologi asites tersebut menjadi amat mencabar. Beberapa kemungkinan punca asitesnya termasuklah metastasis karsinoma payudara, HCL, sirosis hati dengan hipertensi portal dan tuberkulosis peritoneum. Ujian sitologi cecair peritoneum menunjukkan limfosit yang kelihatan matang namun tiada sel malignan. Menariknya, analisis sitometri aliran cecair peritoneum menunjukkan kehadiran populasi sel B klonal dengan sekatan rantai ringan lambda. Oleh itu, disimpulkan bahawa asites tersebut merupakan manifestasi HCL. Beberapa bulan kemudian, beliau meninggal dunia akibat septisemia. Kesan asites pada penyakit HCL termasuklah perkembangan penyakit yang pantas, prognosis yang buruk dan kelangsungan hidup yang pendek. Kami menekankan kepentingan imunofenotip selain sitomorfologi dalam membimbing kami untuk mengesahkan etiologi asites pada pesakit haematologi dan kemaglinanan organ pejal.

Kata kunci: Asites; imunofenotip; leukaemia sel berbulu; sitometri aliran 


\section{INTRODUCTION}

Hairy cell leukaemia (HCL) is a rare indolent chronic B-cell lymphoproliferative disorder characterized by abnormal small mature B-lymphoid cells with hairy cytoplasmic projections in peripheral blood, bone marrow and splenic red pulp, splenomegaly, and a variable degree of cytopenias. HCL is an uncommon malignancy, representing approximately $2 \%$ of all leukaemia and less than $1 \%$ of lymphoid neoplasms (Morton et al. 2006).

We report an interesting case to demonstrate the diagnostic challenge in detecting the cause of ascites which is an unusual manifestation of HCL. The possible causes of ascites and approach in determining its specific cause are discussed, with an emphasis on the significant added value of flow cytometry analysis of peritoneal fluid (ascitic fluid) in making diagnosis.

\section{CASE REPORT}

In 2008, a 72-year-old lady, with hypertension, presented with 3-month-history of loss of weight and 1-monthhistory of pain in left upper abdomen. On examination, there were hepatomegaly $(3 \mathrm{~cm}$ below the right costal margin), splenomegaly ( $5 \mathrm{~cm}$ below the left costal margin) and bilateral inguinal lymphadenopathy. Full blood count (FBC) showed mild anaemia (haemoglobin $10.4 \mathrm{~g} / \mathrm{dL}$ ), white cell count $10.5 \times 10^{9} / \mathrm{L}$, lymphocytosis $\left(6.4 \times 10^{9} / \mathrm{L}\right)$, normal neutrophil count $\left(3.5 \times 10^{9} / \mathrm{L}\right)$, normal monocyte count $\left(0.6 \times 10^{9} / \mathrm{L}\right)$ and normal platelet count $\left(164 \times 10^{9} / \mathrm{L}\right)$. Full blood picture $(\mathrm{FBP})$ showed mild anaemia, lymphocytosis with predominantly mature lymphocytes with few smudge cells, no immature cells, no leucoerythroblastic picture and adequate platelets. Immunophenotyping of the gated cells from peripheral blood showed abnormal population of positivity towards CD20 (bright), CD19 (bright), CD11c, lambda restriction, HLA-DR, CD22, CD23, surface IgM (bright), surface IgD (bright), FMC7 and negative for CD5, CD25, CD10. Based on immunophenotyping of peripheral blood, she was diagnosed as B-cell lymphoproliferative disorder in April 2008. At initial diagnosis, bone marrow biopsy was not performed because the elderly lady was not keen for invasive investigations and intensive chemotherapy at that time. She was managed conservatively without any definitive treatment.

In 2009, she was diagnosed as carcinoma of left breast when she presented with a mass in left breast. She had strong family history of carcinoma of breast. Histopathological examination (HPE) of left breast biopsy showed infiltrating ductal carcinoma, Grade II (Modified Bloom and Richardson) and immunohistochemical studies showed that the malignant cells were estrogen receptor (ER) positive $(90 \%)$, progesterone receptor (PR) positive (80\%) and c-erb- B2 negative. She underwent left mastectomy and axillary lymph node dissection (Stage T2N1M0). She received hormone therapy Tamoxifen and she was on regular follow-up under 'Endocrine and Breast' team.

In 2012, she had metastatic carcinoma in left axillary lymph node when she presented with the swelling in left axilla. Work-up for re-staging showed no distant metastasis. Tamoxifen was stopped and she received hormone therapy Anastrozole. She was not keen for lymph node excision at that time.

In 2013 , there was doubling of her leucocyte counts within 6 months. FBC showed mild anaemia (haemoglobin $10.5 \mathrm{~g} / \mathrm{dL}$ ), leucocytosis $\left(23.1 \times 10^{9} / \mathrm{L}\right)$, lymphocytosis $\left(18.8 \times 10^{9} / \mathrm{L}\right)$, normal neutrophil count $\left(2.9 \times 10^{9} / \mathrm{L}\right)$, high monocyte count $\left(1.2 \times 10^{9} / \mathrm{L}\right)$ and thrombocytopenia $\left(94 \times 10^{9} / \mathrm{L}\right)$. FBP showed mild anaemia, lymphocytosis, predominantly lymphocytes which were small, mature-looking, with clumped nuclear chromatin and inconspicuous nucleoli, occasional abnormal lymphocytes with hairy cytoplasmic projections (Figure 1). Bone marrow aspirate showed 39\% abnormal lymphoid cells which were small, mature-looking, with clumped nuclear chromatin, inconspicuous nucleoli and hairy cytoplasmic projections (Figure 1). Immunophenotyping of the bone marrow aspirate showed abnormal population expressing CD20, CD19, CD11c, CD23 (heterogeneous), CD25 (dim), strong surface IgM and FMC7 with lambda restriction and negative for CD3, CD5, CD56, CD10. In view of morphological and clinical findings, the immunophenotyping result was consistent with hairy cell leukaemia. Bone marrow trephine biopsy showed hypercellular marrow, presence of abnormal mature lymphocytes which were small to medium sized, with diffuse interstitial infiltration pattern as well as nodular aggregates, and fried-egg appearance in areas. Immunohistochemical staining of bone marrow trephine biopsy showed the abnormal lymphoid cells which were positive for $\mathrm{CD} 20, \mathrm{CD} 11 \mathrm{c}$, lambda light chain restriction but were negative for CD3, CD5, CD10, CD23, Cyclin D1; and Ki67 (proliferative index) stain was low (5\%) (Figure 2). Bone marrow biopsy examination was consistent with HCL. she was diagnosed as hairy cell leukaemia in 2013. For risk stratification, she had large splenomegaly and leucocytosis as poor prognostic factors. She was not keen to receive chemotherapy which was intensive or by injection. She opted for oral chemotherapy (monthly pulses of Chlorambucil+Prednisolone for 8 cycles). Assessment of response after treatment showed persistence of disease (stable disease). And hence, Chlorambucil+Prednisolone were given until 2015, when she had carcinoma of right breast.

In March 2015, following counselling during followup visit under 'Endocrine and Breast' team, she agreed to undergo excision of regional lymph nodes (left axillary lymph node dissection) for metastatic carcinoma of left axillary lymph node (ER positive, primary from the breast). In December 2015, she was diagnosed as carcinoma of right breast when she presented with a nodule in right breast. 
HPE of right breast biopsy showed invasive carcinoma of no special type. She underwent right mastectomy with sentinel lymph node biopsy (Stage T1N0M0).

In 2016, she developed symptomatic massive splenomegaly, but she was not keen for intensive chemotherapy. Therefore, she was given palliative splenic irradiation. Then, she was managed conservatively until September 2018, when she had progressive abdominal distension and pain.

Since September 2018, she presented with recurrent ascites which needed frequent, regular peritoneal paracentesis. FBC showed haemoglobin $10.6 \mathrm{~g} / \mathrm{dL}$, white cell count $15.6 \times 10^{9} / \mathrm{L}$, lymphocyte $11.8 \times 10^{9} / \mathrm{L}$, neutrophil $1.6 \times 10^{9} / \mathrm{L}$, monocyte $2.2 \times 10^{9} / \mathrm{L}$, platelet $68 \times 10^{9} /$ L. FBP showed $30 \%$ abnormal lymphoid cells. Following counselling, the patient opted for Chlorambucil+Prednisolone.

Since she had two malignancies (HCL and carcinoma of breast), determining the aetiology of ascites was challenging. There was no history of alcoholism. Ultrasound abdomen showed the liver, which was coarse in echotexture with irregular liver margin, 2 target lesions in segment III and IVb of liver (measuring $1.4 \times 1.6$ $\mathrm{cm}$ and $1.8 \times 2.5 \mathrm{~cm}$, respectively), enlarged portal node anterior to inferior vena cava (measuring $2.6 \times 4 \mathrm{~cm}$ ), grossly enlarged spleen (approximately $21 \mathrm{~cm}$ ), ascites and portal hypertension. Screening tests for hepatitis B and $\mathrm{C}$ viruses were negative. Liver function test showed albumin $33 \mathrm{~g} / \mathrm{L}$, total protein $60 \mathrm{~g} / \mathrm{L}$, total bilirubin $15.2 \mu \mathrm{mol} / \mathrm{L}$, alanine aminotransferase (ALT) $16 \mathrm{U} / \mathrm{L}$, alkaline phosphatase (ALP) $295 \mathrm{U} / \mathrm{L}$ and serum lactate dehydrogenase (LDH) level was $222 \mathrm{U} / \mathrm{L}$. The peritoneal fluid (ascitic fluid) was haemoserous. The serum-to-ascites albumin gradient (SAAG) was less than $11 \mathrm{~g} / \mathrm{L}$. There was no evidence of spontaneous bacterial peritonitis nor peritoneal tuberculosis. Acid-Fast Bacilli (AFB) stain (Ziehl-Neelsen stain) of peritoneal fluid was negative. Mycobacterium culture and sensitivity (C\&S) of peritoneal fluid showed no Mycobacterium isolated after 6 weeks. Peritoneal fluid C\&S showed no bacteria or fungal growth. Cytology of peritoneal fluid showed mature-looking lymphocytes but no malignant cells. Interestingly, flow cytometry analysis of peritoneal fluid showed presence of clonal B cell population with lambda light chain restriction (Figure 3). The report of immunophenotyping of peritoneal fluid described that CD19+ 1ymphoid population showed lambda light chain restriction and was positive for CD45 (bright), CD20, FMC7, surface IgM and CD25 (dim). Therefore, it was concluded that her ascites was an unusual manifestation of HCL. She opted for the best supportive care. In January 2019, she succumbed to septicaemia with underlying HCL.

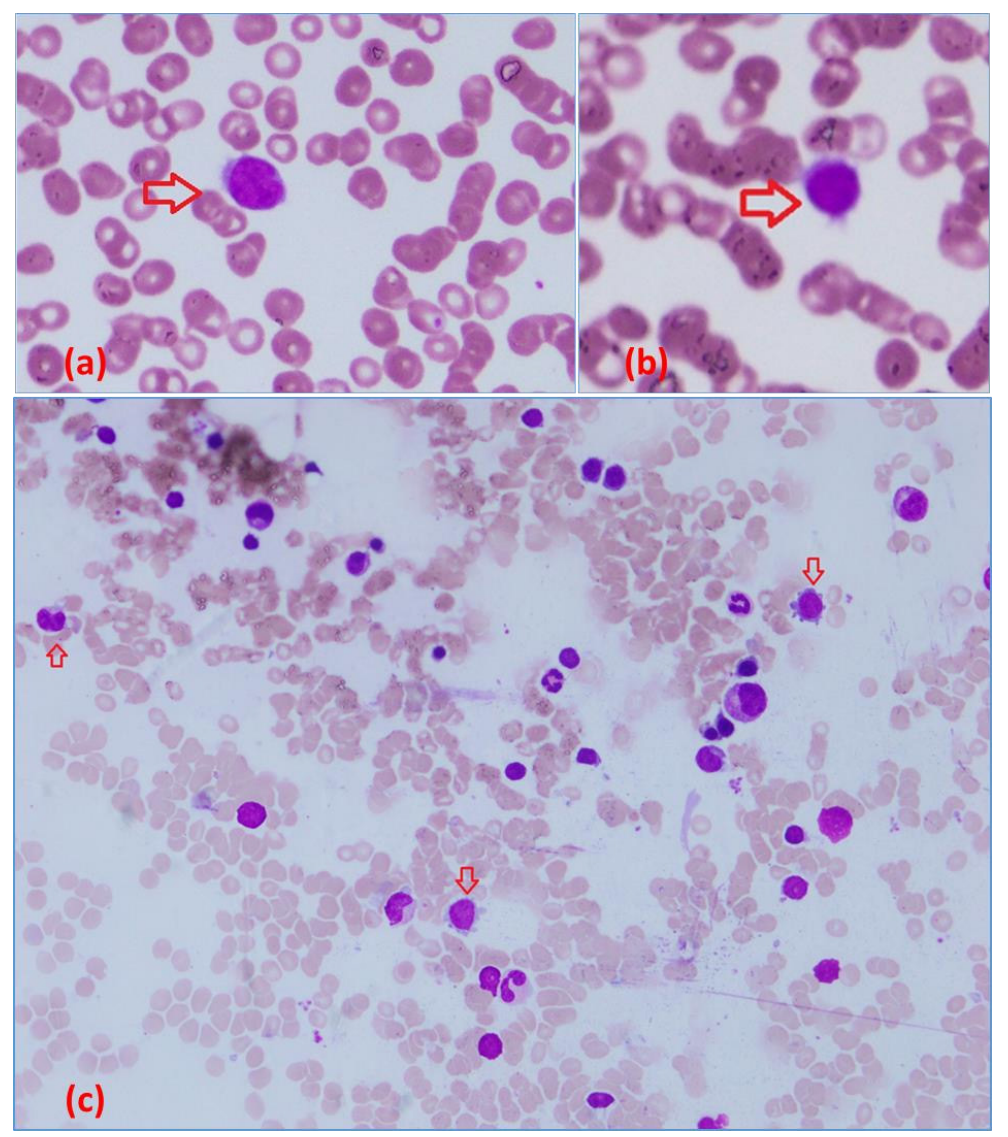

FIGURE 1. Full blood picture (FBP) and bone marrow aspirate findings (a-b) FBP (Wright stain) abnormal lymphocytes with hairy cytoplasmic projections (arrow), (c) Bone marrow aspirate (MGG (May-Grünwald-Giemsa) stain $\times 40$ ) abnormal lymphoid cells with hairy cytoplasmic projections (arrow) 


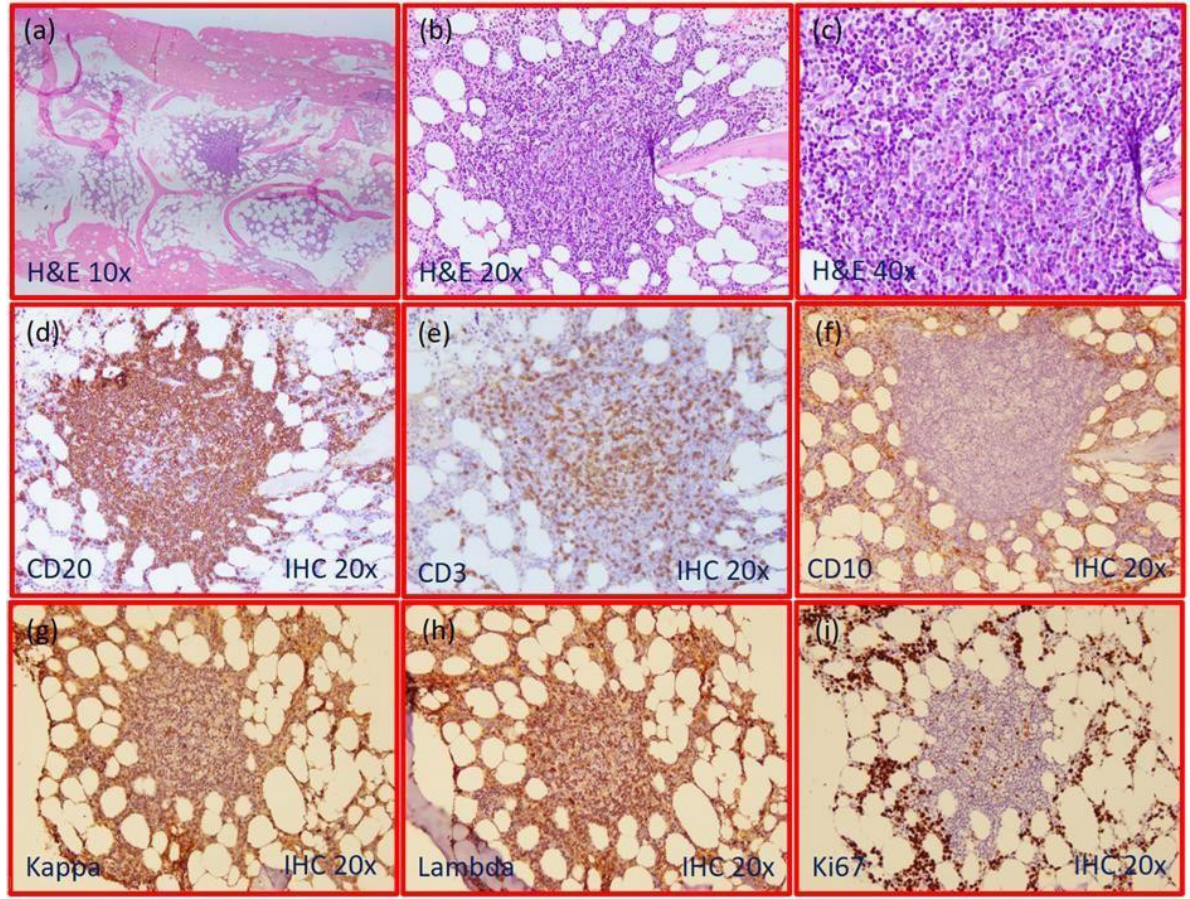

FIGURE 2. Bone marrow trephine biopsy findings (a-c) Haematoxylin and Eosin stain

(H\&E) showed interstitial infiltration of abnormal small-to-medium-sized mature lymphocytes, forming mainly nodular aggregates and displaying occasional fried-egg appearance in areas, (d-f) Immunohistochemistry stain (IHC) showed that the abnormal lymphoid cells were positive for CD20 but negative for CD3 and CD10, (g-h) Lambda light chain restriction, and (i) Ki67 showing 5\% proliferative index
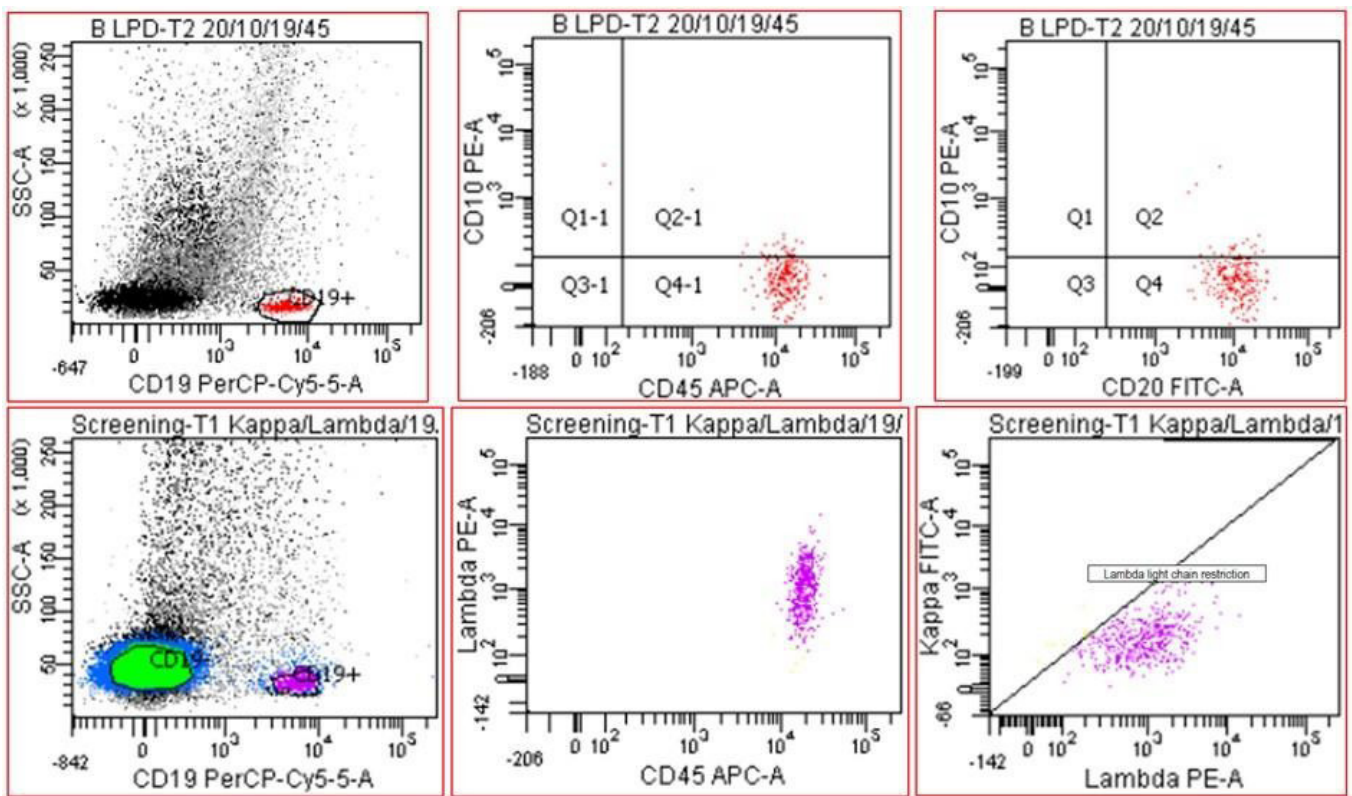

FIGURE 3. Immunophenotyping of peritoneal fluid showing presence of clonal B cell population with lambda light chain restriction 


\section{DISCUSSION}

Overall, survival of our HCL patient was 10.75 years. As HCL is chronic indolent B-LPD, her disease was quite stable until development of ascites. Time of development of ascites from diagnosis was 10.4 years. After developing ascites, her disease progressed rapidly, and she survived only 4.6 months after diagnosis of ascites, indicating that onset of ascites in HCL leads to poor prognosis and shortened survival.

Regarding risk stratification of HCL, poor prognostic factors include large splenomegaly $(>3 \mathrm{~cm})$, leucocytosis $\left(>10 \times 10^{9} / \mathrm{L}\right)$, a high number of hairy cells in the peripheral blood $\left(>5 \times 10^{9} / \mathrm{L}\right)$, high beta- 2 microglobulin $(>2 \mathrm{~N})$, CD38 expression, unmutated IGHV (immunoglobulin heavy chain variable region gene), positive IGHV4-34 (immunoglobulin variable heavy chain rearrangement) and short telomere length (Maitre et al. 2019). Our patient had 2 poor prognostic factors which can be identified, i.e. large splenomegaly and leucocytosis. Other prognostic factors could not be applied for our patient since those investigations were not performed.

At the time of diagnosis, the patient had typical presentation of HCL, i.e. splenomegaly. The common clinical presentations of HCL include consequences of splenomegaly and consequences of cytopenia such as symptoms of anaemia, infection and bleeding manifestation due to thrombocytopenia. Approximately $25 \%$ of HCL patients may be asymptomatic and diagnosed by incidental finding of splenomegaly or cytopenia during routine medical check-up for other disease. To the best of our knowledge, there were very few case reports reporting ascites as an unusual presentation of HCL (Arora et al. 2015; Bouroncle et al. 1987; Davies et al. 1977; Dinçol et al. 2008; Kayal et al. 2011; Shackelford et al. 2013). We present a unique case of HCL, manifesting with ascites during the course of disease, with an emphasis on the significant added value of flow cytometry analysis of peritoneal fluid (ascitic fluid) in making diagnosis.

Ascites can occur as a rare, unique manifestation of HCL. First of all, since our patient had two malignancies, i.e. HCL and carcinoma of breast, determining the aetiology of ascites was challenging. The possible causes of ascites in this patient included metastasis from carcinoma of breast, ascites due to HCL, cirrhosis of liver with portal hypertension and peritoneal tuberculosis in view of her immunocompromised state. Therefore, further investigations are required to ascertain the cause. Secondly, the result of cytology of peritoneal fluid described mature-looking lymphocytes (which might not show the morphologic appearance of hairy cells, i.e. hairy cytoplasmic projections). It became clear that this was lymphoproliferative disease by identification of clonality of abnormal lymphoid cells from the flow cytometry analysis of the peritoneal fluid (ascites). It is crucial to promptly identify the cause of ascites because it has significant impact on therapeutic direction and prognosis. We would like to highlight the important role of performing flow cytometry analysis of peritoneal fluid in addition to cytomorphology so that the diagnostic challenge can be sorted out.

Serous effusions can be detected in haematological malignancies. The common sites of involvement are pleural cavity, followed by peritoneal cavity and pericardial cavity (Tong et al. 2013). Diagnosis of peritoneal carcinomatosis is often dependent on the finding of malignant cells in ascitic fluid analysis by a trained cytologist. Flow cytometry is a rapid and useful technique in the diagnosis of malignant ascites (Weissman et al. 1987). Careful haematopathological assessment and clinical correlation are required for accurate diagnosis of unusual cases of HCL. We highlight the awareness of utilizing flow cytometry (immunophenotyping) of peritoneal fluid in addition to performing the routine cytology in order to make sure that the aetiology of ascites as HCL would not be missed.

For lymphocyte-rich effusion, determination of the definite cause whether lymphocytosis is reactive or malignant (lymphoma) is extremely important as it has an impact on diagnosis, prognosis and therapeutic direction. Application of flow cytometry in adjunct to cytomorphology for examination of body cavity fluid has proven to be very useful for detection in the setting of the development of effusion in a known haematological malignancy as well as in the setting of presenting feature in a newly diagnosed lymphoma. In the study by Cesana et al. (2010), flow cytometry displayed a higher diagnostic performance than cytomorphology in the analysis of serous effusions (sensitivity, $96 \%$ vs $60 \%$ ). In their study, concordant results between flow cytometry and cytomorphology were observed in 69 cases (75\%); discordant results between flow cytometry and cytomorphology were observed in 23 cases $(25 \%)$; and flow cytometry gave false negative result in 1 case (1\%) with true positive cytomorphology.

Another interesting point was that our patient had co-existence of two malignancies, i.e. HCL and carcinoma of breast. In literature review, there was high frequency of second malignancy (including carcinoma of breast) in patients with HCL (Au et al. 1998; Cornet et al. 2014; Saven et al. 1998). In the study of 117 patients with 
HCL in British Columbia, the occurrence of second malignancies were studied: $21.3 \%$ (25 patients out of 117) had malignancies diagnosed after HCL, $2.6 \%$ (3 out of 117 ) concurrent with HCL, and $10.2 \%$ (12 out of 117) preceding HCL (Au et al. 1998). In the study of longterm follow-up in 358 patients with HCL after cladribine treatment by Saven et al. (1998), 8\% (27 patients out of 358) developed second neoplasms. In the large, multicentre study of long-term follow-up in 487 patients with HCL in France, $8 \%$ (41 out of 487) presented with malignancies before HCL diagnosis and 10\% (48 out of 487) developed second malignancies after HCL was diagnosed (Cornet et al. 2014). For our patient, even though haematological malignancy was diagnosed one year earlier than carcinoma of breast, she had not received chemotherapy when she was diagnosed as carcinoma of breast. Our patient had strong family history of carcinoma of breast. We postulated that this patient's HCL and carcinoma of breast were de novo rather than therapy-related disease due to prior treatment.

Regarding definitive treatment for HCL, many patients do not require immediate therapy, and the indications for initiating treatment need to be firmly established. At diagnosis, in 2008, our elderly lady who was 72-year-old, was not keen for invasive investigations and intensive chemotherapy. She was managed with a conservative approach and close follow-up. As literature review, the 2020 update on treatment on HCL is discussed (Maitre et al. 2019). For patients with HCL who are asymptomatic, 'watch and wait strategy' is recommended with the following reasons: (1) there is no clear advantage to early therapy, (2) there is a theoretic risk of infection, occasionally with opportunistic organisms, and (3) the goal of treatment is to alleviate symptoms, reverse cytopenia and prolong survival to a near normal lifespan. Definitive treatment is indicated when there is indication for treatment. Indications for treatment include significant cytopenias (haemoglobin concentration $<11 \mathrm{~g} / \mathrm{dL}$, absolute neutrophil count $<1000 / \mu \mathrm{L}$ or platelet count $<100,000 / \mu \mathrm{L}$ ), systemic symptoms (unexplained weight loss $(>10 \%$ within prior 6 months), excessive fatigue), symptomatic splenomegaly (common) or symptomatic adenopathy (uncommon), less severe cytopenias that are symptomatic (e.g. repeated infections, bleeding), progressive lymphocytosis or progressive lymphadenopathy (Grever et al. 2017). Risk-adapted therapy with purine nucleoside analogs (cladribine or pentostatin) is indicated as first-line therapy in symptomatic HCL patients (Maitre et al. 2019). Cladribine is preferred over pentostatin because of ease of administration and shorter treatment duration. Chemoimmunotherapy (initial treatment with cladribine followed by consolidation therapy with rituximab) is an alternative option. Interferon alfa may be preferred in the following settings: for patients who require treatment but have active infection (to improve blood counts and allow for subsequent therapy with purine analogs), and for patients requiring treatment during pregnancy (Maitre et al. 2019). For treatment of resistant disease (for the rare patients who do not respond to initial therapy with a purine analog), an alternative purine analog (i.e. pentostatin in those who have received cladribine, and vice versa) \pm rituximab is suggested. Treatment options for relapsed/ refractory HCL include vemurafenib, moxetumomab pasudotox, interferon alfa, single-agent rituximab, bendamustine plus rituximab or other investigational therapies (Maitre et al. 2019).

\section{CONCLUSION}

This case report highlights the significant added value of performing flow cytometry analysis (immunophenotyping) in addition to cytomorphology to guide us in confirming the aetiology of ascites by identifying the clonality of mature-looking lymphocytes in a patient with two malignancies (haematological and solid organ malignancies).

\section{ACKNOWLEDGEMENTS}

Acknowledgment was made to the patient who had given the informed written consent for publication of this case report. The authors have no conflict of interest to declare.

\section{REFERENCES}

Arora, N., Mishra, A., Santra, P. \& Nair, R. 2015. Hairy cell leukaemia with ascites and coexistent histoplasmosis. Indian Journal of Pathology and Microbiology 58(1): 125126.

Au, W.Y., Klasa, R.J., Gallagher, R., Le, N., Gascoyne, R.D. \& Connors, J.M. 1998. Second malignancies in patients with hairy cell leukaemia in British Columbia: A 20-year experience. Blood 92(4): 1160-1164.

Bouroncle, B.A. 1987. Unusual presentations and complications of hairy cell leukaemia. Leukaemia 1(4): 288-293.

Cesana, C., Klersy, C., Scarpati, B., Brando, B., Volpato, E., Bertani, G., Faleri, M., Nosari, A., Cantoni, S., Ferri, U. \& Scampini, L. 2010. Flow cytometry vs cytomorphology for the detection of haematologic malignancy in body cavity fluids. Leukaemia Research 34(8): 1027-1034.

Cornet, E., Tomowiak, C., Tanguy-Schmidt, A., Lepretre, S., Dupuis, J., Feugier, P., Devidas, A., Mariette, C., Leblond, V., Thiéblemont, C. \& Validire-Charpy, P. 2014. Long-term follow- up and second malignancies in 487 patients with hairy cell leukaemia. British Journal of Haematology 166(3): 390-400. 
Davies, G.E. \& Wiernik, P.H. 1977. Hairy cell leukaemia with chylous ascites. JAMA 238(14): 1541-1542.

Dinçol, G., Dogan, Ö., Küçükkaya, R.D., Gül, E., Kahraman, R. \& Agan, M. 2008. Hairy cell leukaemia presenting with ascites, pleural effusion and increased CA 125 serum level. The Netherlands Journal of Medicine 66(1): 23-26.

Grever, M.R., Abdel-Wahab, O., Andritsos, L.A., Banerji, V., Barrientos, J., Blachly, J.S., Call, T.G., Catovsky, D., Dearden, C., Demeter, J., Else, M., Forconi, F., Gozzetti, A., Ho, A.D., Johnston, J.B., Jones, J., Juliusson, G., Kraut, E., Kreitman, R.J., Larratt, L., Lauria, F., Lozanski, G., Montserrat, E., Parikh, S.A., Park, J.H., Polliack, A., Quest, G.R., Rai,K.R., Ravandi, F., Robak, T., Saven, A., Seymour, J.F., Tadmor, T., Tallman, M.S., Tam, C., Tiacci, E., Troussard, X., Zent, C.S., Zenz, T., Zinzani, P.L. \& Falini, B. 2017. Consensus guidelines for the diagnosis and management of patients with classic hairy cell leukaemia. Blood 129(5): 553-560.

Kayal, S., Radhakrishnan, V., Singh, S., Chopra, A., Kumar, R. \& Raina, V. 2011. Hairy cell leukaemia with ascites: An unusual presentation. Leukaemia \& Lymphoma 52(3): 539-540.

Maitre, E., Cornet, E. \& Troussard, X. 2019. Hairy cell leukaemia: 2020 update on diagnosis, risk stratification, and treatment. American Journal of Hematology 94(12): 1413-1422.

Morton, L.M., Wang, S.S., Devesa, S.S., Hartge, P., Weisenburger, D.D. \& Linet, M.S. 2006. Lymphoma incidence patterns by WHO subtype in the United States, 1992-2001. Blood 107(1): 265-276.

Saven, A., Burian, C., Koziol, J.A. \& Piro, L.D. 1998. Longterm follow-up of patients with hairy cell leukaemia after cladribine treatment. Blood 92(6): 1918-1926.

Shackelford, R.E., Heldmann, M., Eskandari, F., Joshi, N., Browning, J., Maxwell, N. \& Coteligam, J. 2013. Marked retroperitoneal lymphadenopathy in hairy cell leukaemia: A case report. Case Reports in Oncology 6(3): 493-496.
Tong, L.C., Ko, H.M., Saieg, M.A., Boerner, S., Geddie, W.R. \& da Cunha Santos, G. 2013. Subclassification of lymphoproliferative disorders in serous effusions: A 10-year experience. Cancer Cytopathology 121(5): 261-270.

Weissman, G.S., McKinley, M.J., Budman, D.R., Caccese, W.J., Schulman, P., Grueneberg, D. \& Bronzo, R.L. 1987. Flow cytometry. A new technique in the diagnosis of malignant ascites. Journal of Clinical Gastroenterology 9(5): 599602.

Wint Wint Thu Nyunt, Noralisa Abdul Karim \& S Fadilah S Abdul Wahid*

Pusat Terapi Sel

Faculty of Medicine

Hospital Canselor Tuanku Muhriz UKM

56000 Kuala Lumpur, Federal Territory Malaysia

Azian Naila binti Md Nor \& Tang Yee Loong

Department of Pathology, Faculty of Medicine Hospital Canselor Tuanku Muhriz UKM

56000 Kuala Lumpur, Federal Territory Malaysia

Nor Rafeah Tumian

Department of Medicine, Faculty of Medicine

Hospital Canselor Tuanku Muhriz UKM

56000 Kuala Lumpur, Federal Territory

Malaysia

*Corresponding author; email: sfadilah@ppukm.ukm.edu.my

Received: 3 January 2020

Accepted: 30 September 2020 